\title{
Eyelid Carcinoma Pathologic TNM Finding v8
}

National Cancer Institute

\section{Source}

National Cancer Institute. Eyelid Carcinoma Pathologic TNM Finding v8. NCI Thesaurus. Code C140482.

A pathologic finding about one or more characteristics of eyelid carcinoma, following the rules of the TNM AJCC v8 classification system. 